\title{
ДОСЛІДЖЕННЯ АМІНОКИСЛОТНОГО СКЛАДУ ЧОРНОБРИВЦІВ ТРАВИ ЕКСТРАКТУ СУХОГО
}

Вступ. Амінокислоти рослинного походження легко засвоюються і перебувають у біологічно доступних для організму людини концентраціях. Тому дослідження їх у лікарській рослинній сировині та фрітопрепаратах має велике наукове і практичне значення.

Мета дослідження - вивчити якісний склад та кількісний вміст амінокислот у чорнобривців розлогих трави екстракті сухому.

Методи дослідження. Ідентифрікацію та визначення кількісного вмісту вільних ізв'язаних амінокислот в екстракті сухому, отриманому з чорнобривців розлогих трави, проводили методом високоефективноі рідинної хроматографрії (ВEPX).

Результати й обговорення. За результатами BEPX-аналізу, в чорнобривців розлогих трави екстракті сухому ідентисріковано 17 амінокислот, з яких $9 €$ незамінними. Встановлено, що у складі екстракту переважали зв'язані амінокислоти. Так, у відсотковому еквіваленті вміст зв'язаних у складі білка амінокислот становив 97,52 \%, тоді як вільних амінокислот - лише 2,48 \%. Серед незамінних амінокислот домінували лізин (97,76 мкг/м2), лейцин (80,19 мкг/м2), френілаланін (54,76 мкг/мг) та ізолейцин (52,40 мкг/мг). Встановлено найнижчий вміст метіоніну у зв'язаному стані й відсутність його у вільному. Серед замінних амінокислот виявлено найбільшу кількість моноамінодикарбонових кислот (глутамінової та аспарагіновоі) і цистину.

Висновки. Досліджено амінокислотний склад чорнобривців розлогих трави екстракту сухого. Методом BEPХ-аналізу вивчено якісний склад і кількісний вміст зв'язаних у складі білка та вільних амінокислот. Одержані результати свідчать про перспективність використання чорнобривців розлогих трави екстракту сухого як потенційного джерела біологічно активних речовин.

КЛЮЧОВІ СЛОВА: сухий екстракт; чорнобривців розлогих трава; амінокислоти; високоесективна рідинна хроматографрія.

ВСТУП. Одними з найважливіших біологічно активних речовин, що синтезують рослини, $€$ комплекс амінокислот, як вільних, так і в складі рослинного білка. Це азотовмісні карбонові кислоти, що одночасно містять аміно- (іміно-) і карбоксильну групи та вуглецевий скелет.

Незважаючи на величезне різноманіття білків, усі вони складаються лише з 20 амінокислот, які називають конституційними. Відомо, що організм людини здатний синтезувати лише 10 амінокислот, решта $€$ незамінними і надходять тільки з їжею (аргінін, валін, гістидин, лейцин, лізин, ізолейцин, метіонін, треонін, триптофран, френілаланін) [1, 2]. Значення цих сполук важко переоцінити, оскільки вони підтримують нормальний розвиток і функціонування організму в цілому. Ґрунтовний аналіз біохімічних властивостей та фрункцій амінокислот наведено в ряді наукових досліджень [2-4].

(с) Г. Р. Козир, 2018.
Амінокислоти рослинного походження легко засвоюються і перебувають у біологічно доступних для організму людини концентраціях, що зумовлює вищу фрізіологічну активність і біодоступність порівняно із синтетичними аналогами [5]. Тому дослідження їх складу і визначення вмісту амінокислот у лікарській рослинній сировині та орітопрепаратах має велике наукове і практичне значення.

У літературі зустрічаються результати досліджень амінокислотного складу чорнобривців розлогих (Tagetes patula) трави [6] та коренів і суцвіття [7]. Під час попередніх досліджень у чорнобривців розлогих траві виявлено 17 амінокислот у зв'язаному стані й 15 - у вільному [6]. Встановлено більший сумарний кількісний вміст зв'язаних амінокислот, ніж вільних, досліджено їх якісний склад та кількісний вміст.

Мета дослідження - вивчити якісний склад та кількісний вміст амінокислот у чорнобривців розлогих трави екстракті сухому. 
МЕТОДИ ДОСЛІДЖЕННЯ. Об'єкТОМ дОслідження був екстракт сухий, отриманий із чорнобривців розлогих трави, вирощених на дослідній ділянці ботанічного саду "Червона калина" Тернопільського державного медичного університету імені І. Я. Горбачевського.

Вільні та зв'язані амінокислоти визначали в екстракті методом високоефективної рідинної хроматограсрії (BEPX). Метод оснований на екстракції вільних амінокислот з екстракту та кислотному гідролізі рослинних препаратів 3 наступним аналізом гідролізатів методом високоефективної рідинної хроматографії з передколонковою дериватизацією 9-срлуоренілметоксикарбоніл хлоридом (FMOC) та о-срталевим альдегідом (ОРА) з наступною детекцією фрлуоресцентним детектором. Флуоресцентні похідні отримували в автоматичному програмованому режимі перед введенням проби в хроматографрічну колонку.

Хроматограсрічне розділення проводили на рідинному хроматограсрі Agilent 1200 (Agilent technologies, США). Колонка Zorbax ААА довжиною 150 мм, внутрішнім діаметром 4,6 мм, діаметр зерна сорбенту - 3 мкм. Мобільна фраза А $40 \mathrm{mM} \mathrm{Na} \mathrm{HPO}_{4}(\mathrm{pH} 7,8) ; \mathrm{B}$ - ACN:MeOH:water $(45: 45: 10, v / v / v)$. Режим розділення градієнтний із постійною швидкістю потоку 1,5 мл/хв. Температура термостата колонки $-40{ }^{\circ} \mathrm{C}$. Передколонкову дериватизацію проводили в автоматичному програмованому режимі з використанням FMOC реагенту (Agilent 5061-3337) та OPA реагенту (Agilent 5061-3335). Детекція дерива- тизованих амінокислот реалізовувалася за допомогою фрлуоресцентного детектора [8-11].

Ідентифрікацію амінокислот проводили шляхом порівняння часів утримання із сумішшю стандартів амінокислот (Agilent 5061-3334). Вміст зв'язаних амінокислот визначали, віднімаючи вміст вільних амінокислот від їх загального вмісту.

РЕЗУЛЬТАТИЙ ОБГОВОРЕННЯ. За РеЗУЛЬтатами BEPX-аналізу, в чорнобривців розлогих трави екстракті сухому ідентисіковано 17 амінокислот, з яких $9 €$ незамінними (гістидин, треонін, аргінін, валін, метіонін, оренілаланін, ізолейцин, лейцин, лізин). Результати визначення якісного складу та кількісного вмісту амінокислот у чорнобривців розлогих трави екстракті сухому наведено в таблиці й на рисунках 1, 2.

Згідно з отриманими результатами, встановлено, що, як і в чорнобривців розлогих траві [6], у складі екстракту переважали зв'язані амінокислоти. Так, у відсотковому еквіваленті вміст зв'язаних у складі білка амінокислот становив 97,52 \%, тоді як вільних амінокислот - лише $2,48 \%$.

Щодо незамінних амінокислот, то виявлено найвищий сумарний вміст як зв'язаних у складі білка, так і вільних амінокислот: лізину 97,76 мкг/мг, лейцину - 80,19 мкг/мг, френілаланіну - 54,76 мкг/мг та ізолейцину - 52,40 мкг/мг. Як видно з рисунка 1, найбільша їх кількість була у зв'язаному стані.

Відомо, що лізин забезпечує ріст кісткової тканини, бере участь у синтезі антитіл, гормонів,

Таблиця - Вміст амінокислот у чорнобривців розлогих трави екстракті сухому

\begin{tabular}{|c|c|c|}
\hline \multirow{2}{*}{ Назва амінокислоти } & \multicolumn{2}{|c|}{ Вміст амінокислот, мкг/мг } \\
\hline & вільних & зв'язаних \\
\hline \multicolumn{3}{|c|}{ Незамінні амінокислоти } \\
\hline Гістидин & 1,22 & 22,12 \\
\hline Треонін & 1,00 & 47,12 \\
\hline Аргінін & 3,03 & 47,69 \\
\hline Валін & 1,58 & 50,70 \\
\hline Метіонін & 0,00 & 13,37 \\
\hline Фенілаланін & 1,31 & 53,45 \\
\hline Ізолейцин & 0,51 & 51,89 \\
\hline Лейцин & 0,32 & 79,87 \\
\hline Лізин & 0,96 & 96,80 \\
\hline \multicolumn{3}{|c|}{ Замінні амінокислоти } \\
\hline Аспарагінова кислота & 1,92 & 96,42 \\
\hline Глутамінова кислота & 6,13 & 169,23 \\
\hline Серин & 1,64 & 45,70 \\
\hline Гліцин & 0,18 & 56,87 \\
\hline Аланін & 1,12 & 56,54 \\
\hline Тирозин & 1,09 & 23,08 \\
\hline Цистин & 0,92 & 143,12 \\
\hline Пролін & 5,26 & 56,89 \\
\hline Сума незамінних амінокислот, мкг/мг & 9,93 & 463,01 \\
\hline Сума замінних амінокислот, мкг/мг & 18,26 & 647,85 \\
\hline Загальна сума амінокислот, мкг/мг & 29,19 & 1110,86 \\
\hline
\end{tabular}




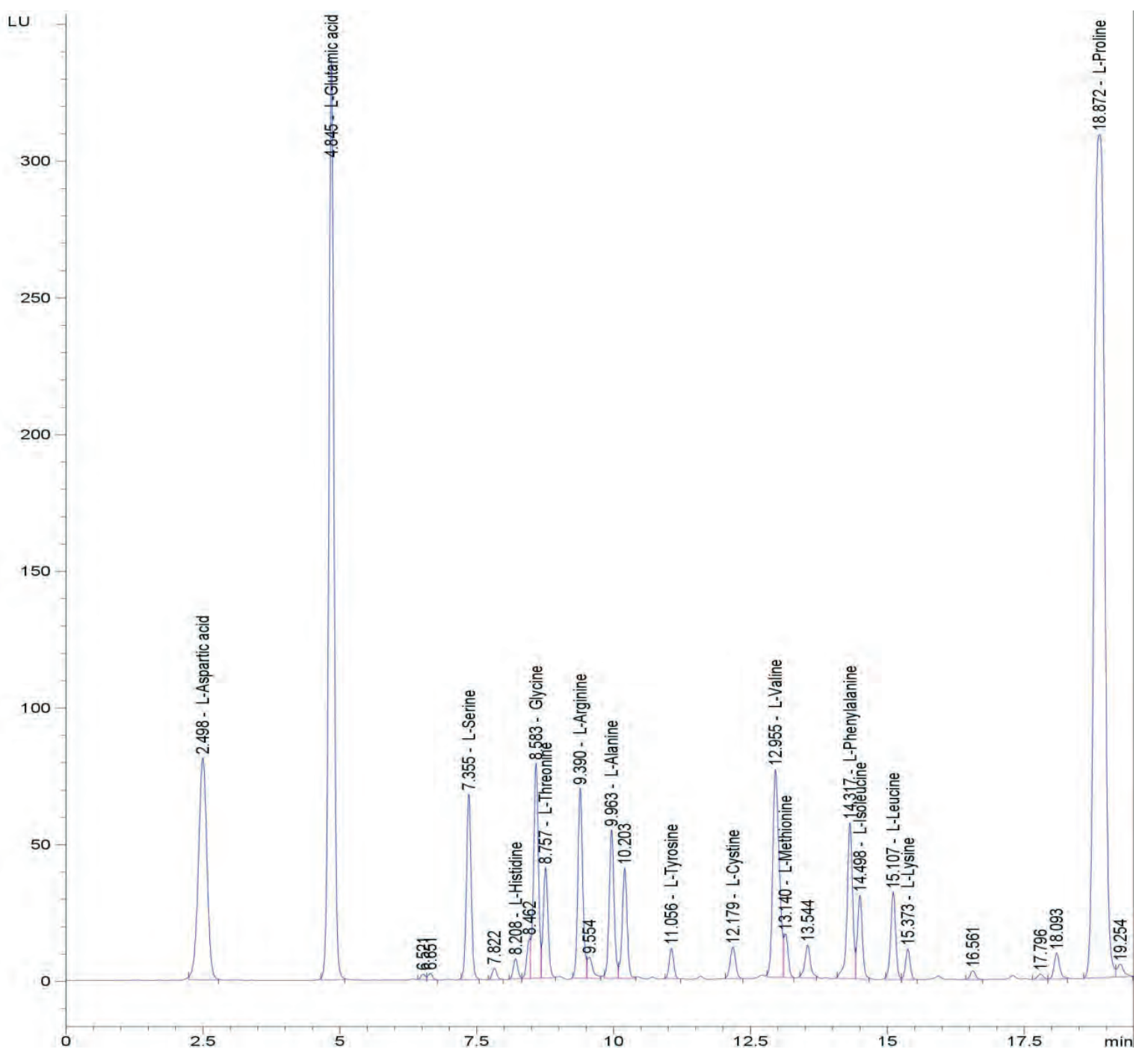

Рис. 1. Хроматограма загальних амінокислот у чорнобривців розлогих трави екстракті сухому.

фрерментів, фрормуванні колагену і відновленні тканин [4]. Лейцин захищає м'язові тканини тає джерелом енергії, а також сприяє відновленню кісток, шкіри, м'язів, дещо знижує рівень цукру в крові й стимулює виділення гормону росту. Фенілаланін в організмі може перетворюватися на іншу амінокислоту - тирозин, яка, у свою чергу, використовується в синтезі двох основних нейромедіаторів: допаміну і норадреналіну. Тому ця амінокислота впливає на настрій, зменшує біль, покращує пам'ять і здатність до навчання, пригнічує апетит. Ізолейцин - одна з незамінних амінокислот, необхідних для синтезу гемоглобіну, він також стабілізує і регулює рівень цукру в крові та процеси енергозабезпечення [1-4].

Серед незамінних амінокислот у вільному стані найвищий вміст аргініну - 3,03 мкг/мг, валіну - 1,58 мкг/мг та френілаланіну - 1,31 мкг/мг. Слід зазначити відсутність у вільному стані метіоніну та найменшу його кількість у зв'язаному стані - 13,37 мкг/мг, що є найнижчим показником з усіх амінокислот.

У результаті проведених досліджень встановлено, що з усіх амінокислот переважали замінні. Як видно з таблиці, в досліджуваному екстракті домінували моноамінодикарбонові кислоти - глутамінова й аспарагінова. Виявлено найвищий сумарний вміст як зв'язаних у складі білка, так і вільних амінокислот: глутамінової кислоти - 175,37 мкг/мг, цистину - 144,05 мкг/Мг та аспарагінової кислоти - 98,34 мкг/мг.

Відомо, що глутамінова кислота бере участь у білковому обміні, підтримує дихання клітин головного мозку, кислотно-лужний гомеостаз крові та тканин [4]. Вона є попередником синтезу орнітину і проліну, сприяє тимчасовому знешкодженню аміаку з утворенням нетоксичного глутаміну [5].

Цистин фрормує та підтримує третинну структуру білків і пептидів, входить до складу імуноглобулінів, інсуліну та соматостатину. Лікарські 


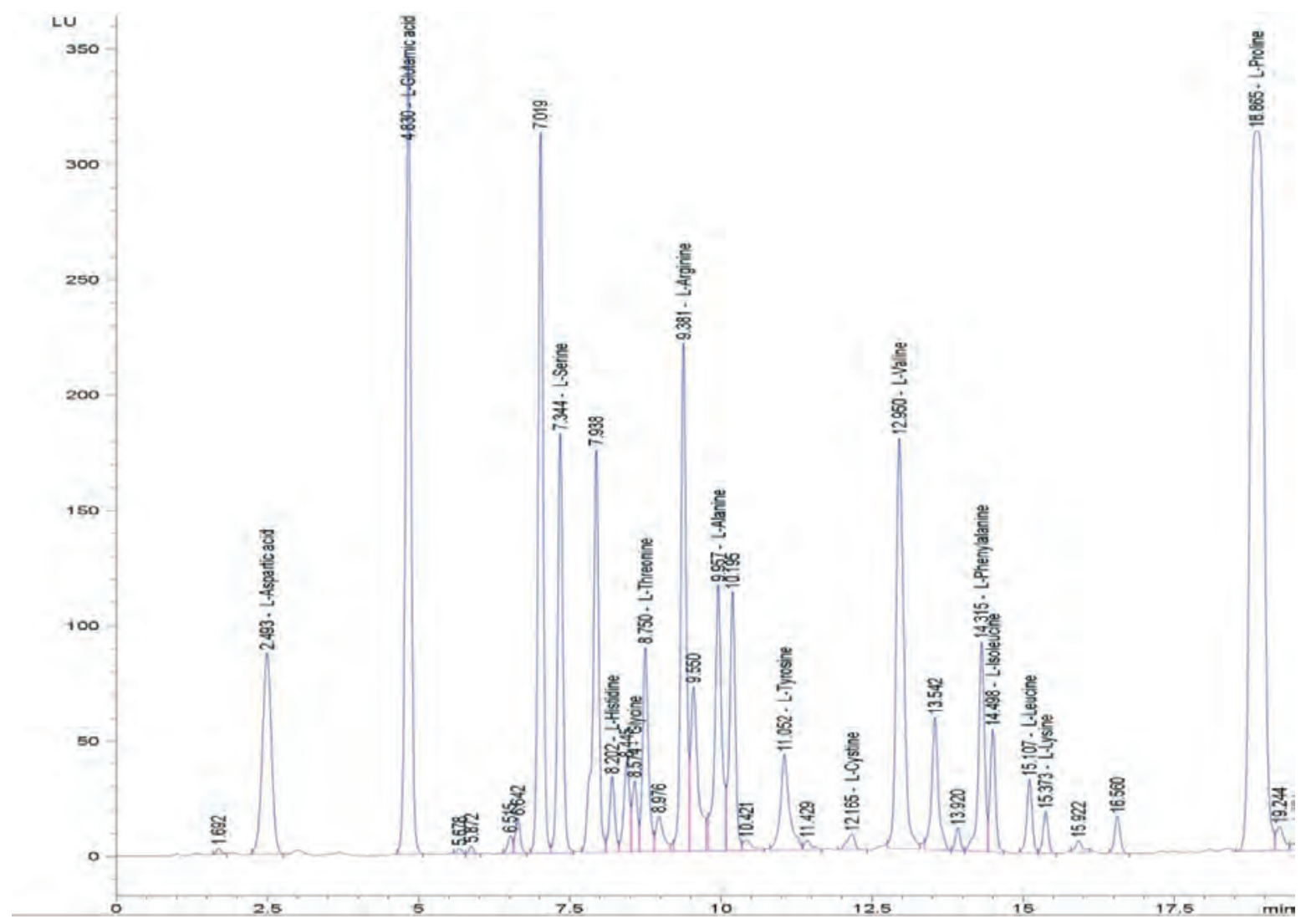

Рис. 2. Хроматограма вільних амінокислот у чорнобривців розлогих трави екстракті сухому.

засоби на основі цистину проявляють гепатотропний, антиоксидантний, детоксикаційний, репаративний, імуномодулюючий, ранозагоювальний, муколітичний та відхаркувальний есрект [2-4].

Аспарагінова кислота забезпечує перетворення вуглеводів на енергію м'язів, підвищує активність імунної системи й опірність до втомлюваності, зберігає здатність до роботи і витривалість, має гепатопротекторні властивості, бере участь у реакціях циклу сечовини та переамінування, синтезі метіоніну, треоніну і лізину [5]. Аспарагін здатний зв'язувати аміак у тканинах; підтримує нормальне фрункціонування нервової системи, печінки; перешкоджає як надмірному збудженню, так і зайвому гальмуванню; бере участь у метаболічних процесах; стимулює імунітет [7].

\section{СПИСОК ЛІТЕРАТУРИ}

1. Смирнов В. А. Аминокислоты и полипептиды : учеб. пособ. / В. А. Смирнов, Ю. Н. Климочкин. - Самара : Самар. гос. техн. ун-т, 2007. - Ч. І. - 110 с.
Серед вільних амінокислот найбільше містилося глутамінової кислоти - 3,03 мкг/мг, проліну 5,26 мкг/мг і аспарагінової кислоти - 1,92 мкг/мг.

Таким чином, результати дослідження амінокислотного складу чорнобривців розлогих трави екстракту сухого свідчать про перспективність використання даного екстракту як потенційного джерела біологічно активних речовин.

ВИСНОВКИ. 1. Досліджено амінокислотний склад чорнобривців розлогих трави екстракту сухого, ідентифіковано 17 амінокислот, з яких 9 $€$ незамінними. Методом ВЕРХ-аналізу вивчено якісний склад і кількісний вміст зв'язаних у складі білка та вільних амінокислот.

2. Одержані результати свідчать про перспективність використання чорнобривців розлогих трави екстракту сухого як потенційного джерела біологічно активних речовин.

2. Фармацевтична енциклопедія / гол. ред. Ради та автор передмови В. П. Черних. - 3-тє вид., переробл. і доповн. - К. : МОРІОН, 2016. - 1952 с. 
3. Аминокислоты глазами химиков, срармацевтов, биологов: в 2 т. / [А. О. Сыровая, Л. Г. Шаповал, В. А. Макаров и др.]. - Х. : Щедра садиба плюс, 2014. T. 1. -228 C.

4. Аминокислоты глазами химиков, фрармацевтов, биологов : в 2 т. / [А. О. Сыровая, Л. Г. Шаповал, В. А. Макаров и др.]. - Х. : Щедра садиба плюс, 2015. T. 2. $-268 \mathrm{c}$.

5. Федосов А. І. Дослідження амінокислотного складу артишоку суцвіть / А. І. Федосов // Фармац. часоп. - 2017. - № 3. - С. 25-30.

6. Бердей Т. С. Амінокислотний склад трави деяких видів рослин роду чорнобривців / Т. С. Бердей // Хімія природних сполук : матеріали III Всеукр. наук.практ. конф., 7-8 жовт. 2012 р. - Тернопіль, 2012. C. 7-8.

7. Визначення якісного та кількісного амінокислотного складу суцвіть та коренів чорнобривців розлогих (Tagetes patula L.) [Електронний ресурс] / О. О. Малюгіна, О. В. Мазулін, Г. В. Мазулін, Г. П. Смойловська // Перспективні напрямки вітчизняної науки : матеріали Першої міжнар. наук.-практ. конфр., 13-
18 трав. 2013 р. - Режим доступу : http://nauka.zinet. info/21/malyugina.php.

8. Henderson J. W. Rapid, accurate, sensitive, and reproducible HPLC analysis of amino acids, amino acid analysis using Zorbax Eclipse-AAA columns and the Agilent 1100 HPLC / J. W. Henderson, R. D. Ricker, B. A. Bidlingmeyer [et al.] // Agilent Technical Note. 1999. - P. 5980-1193E.

9. Jámbor A. Quantitation of amino acids in plasma by high performance liquid chromatography: Simultaneous deproteinization and derivatization with 9-fluorenylmethyloxycarbonyl chloride / A. Jámbor, I. MolnárPerl // J. Chromatogr. A. - 2009. - P. 6218-6223.

10. Jámbor A. Amino acid analysis by high-performance liquid chromatography after derivatization with 9-fluorenylmethyloxycarbonyl chloride. Literature overview and further study / A. Jámbor, I. Molnár-Perl // J. Chromatogr. A. - 2009. - P. 3064-3077.

11. Popyk A. The carbohydrates and aminoacids study in common lilac of Charles Joile variety flowers and leaves / A. Popyk, V. Kyslychenko, V. Korol [et al.] // American Journal of Science and Technologies. -2015. No. 2 (20). - P. 779-785.

\section{REFERENCES}

1. Smirnov, V.A., \& Klimochkin, Yu.N. (2007). Aminokisloty i polipeptidy: ucheb. posob. Ch. I. [Amino acids and polypeptides: manual. Part I.] Samara: Samara State Technical University [in Russian].

2. Chernykh, V.P. (2016). Farmatsevtychna entsyklopediia [Pharmaceutical encyclopedia]. Kyiv: MORION [in Ukrainian].

3. Syrovaya, A.O., Shapoval, L.G., Makarov, V.A., Petyunina, V.N., Grabovetskaya, E.R., Andreeva, S.V. et al. (2014). Aminokisloty glazami khimikov, farmatsevtov, biologov: v 2-h t. T. 1 [Amino acids through the eyes of chemists, pharmacists, biologists: in 2 vol. Vol. 1]. Kharkov: Shchedra sadiba plyus [in Russian].

4. Syrovaya, A.O., Shapoval, L.G., Makarov, V.A., Petyunina, V.N., Grabovetskaya, E.R., Andreeva, S.V., Nakonechnaya, S.A. et al. (2015). Aminokisloty glazami khimikov, farmatsevtov, biologov: v 2-h t. T. 2 [Amino acids through the eyes of chemists, pharmacists, biologists: in 2 vol. Vol. 2]. Kharkov: Shchedra sadiba plyus [in Russian].

5. Fedosov, A.I. (2017). Doslidzhennia aminokyslotnoho skladu artyshoku sutsvit [Investigation of the amino acid composition of artichoke inflorescences]. Farmatsevt. chasop. - Pharmaceutical Journal, 3, 25-30 [in Ukrainian].

6. Berdei, T.S. (2012). Aminokyslotnyi sklad travy deiakykh vydiv roslyn rodu chornobryvtsiv [Amino acid composition of the grass of some species of plants of the French marigold]. Materialy III Vseukrainskoi naukovopraktychnoi konferentsii "Khimiia pryrodnykh spoluk" Materials of the III All-Ukrainian Scientific-Practical Conference "Chemistry of Natural Compounds". October 7-8, 2012. Ternopil.(pp.7-8) [in Ukrainian].

7. Maliuhina, O.O., Mazulin, O.V., Mazulin, H.V., \& Smoilovska, H.P. (2013). Vyznachennia yakisnoho ta kilkisnoho aminokyslotnoho skladu sutsvit ta koreniv chornobryvtsiv rozlohykh (Tagetes patula L.) [Determination of qualitative and quantitative amino acid composition of inflorescences and roots of French marigold (Tagetes patula L.)]. Materialy pershoi mizhnar. nauk. -prakt. konf. "Perspektyvni napriamky vitchyznianoi nauky" - Materials of the First International Conference "Perspective Directions of the National Science". May, 13-18. Retrieved from: http://nauka.zinet.info/21/malyugina.php [in Ukrainian].

8. Henderson, J.W., Ricker, R.D., Bidlingmeyer, B.A., Woodward, C. (1999). Rapid, accurate, sensitive, and reproducible HPLC analysis of amino acids. Amino acid analysis using Zorbax Eclipse-AAA columns and the Agilent 1100 HPLC. Agilent Technical Note, 5980-1193E.

9. Jámbor, A., \& Molnár-Perl, I. (2009). Quantitation of aminoacids in plasma by high performance liquid chromatography: Simultaneous deproteinization and derivatization with 9-fluorenylmethyloxycarbonyl chloride. J. Chromatogr. A., 6218-6223.

10. Jámbor, A., \& Molnár-Perl, I. (2009). Aminoacid analysis by high-performance liquid chromatography after derivatization with 9-fluorenylmethyloxycarbonyl chloride. Literature overview and further study. J. Chromatogr. A., 3064-3077.

11. Popyk, A., Kyslychenko, V., Korol, V., \& Gurieva, I. (2015). The carbohydrates and aminoacids study in common lilac of Charles Joile variety flowers and leaves. American Journal of Science and Technologies, 2 (20), 779-785. 


\section{ИССЛЕДОВАНИЕ АМИНОКИСЛОТНОГО СОСТАВА БАРХАТЦЕВ ТРАВЫ ЭКСТРАКТА СУХОГО}

\section{Резюме}

Вступление. Аминокислоты растительного происхождения легко усваиваются и находятся в биологически доступных для организма человека концентрациях. Поэтому исследование их в лекарственном растительном сырье и фритопрепаратах имеет огромное научное и практическое значение.

Цель исследования - изучить качественный состав и количественное содержание аминокислот в бархатцев распростертых травы экстракте сухом.

Методы исследования. Идентификацию и определение количественного содержания свободных и связанных аминокислот в экстракте сухом, полученном из бархатцев распростертых травы, осуществляли методом высокоэфрфективной жидкостной хроматограсрии (ВЭЖХ).

Результаты и обсуждение. По результатам ВЭЖХ-анализа, в бархатцев распростертых травы экстракте сухом идентифицировано 17 аминокислот, из которых 9 являются незаменимыми. Установлено, что в составе экстракта преобладали связанные аминокислоты. Так, в процентном эквиваленте содержание связанных в составе белка аминокислот составлял 97,52%, тогда как свободных аминокислот только 2,48 \%. Среди незаменимых аминокислот доминировали лизин (97,76 мкг/м2), лейцин (80,19 мкг/м2), френилаланин (54,76 мкг/мг) и изолейцин (52,40 мкг/м2). Установлено самое низкое содержание метионина в связанном состоянии и отсутствие его в свободном. Среди заменимых аминокислот обнаружено наибольшее количество моноаминодикарбоновых кислот (глутаминовой и аспарагиновой) и цистина.

Выводы. Исследован аминокислотный состав бархатцев распростертых травы экстракта сухого. Методом ВЭЖХ-анализа изучены качественный состав и количественное содержание связанных в составе белка и свободных аминокислот. Полученные результаты свидетельствуют о перспективности использования бархатцев распростертых травы экстракта сухого как потенциального источника биологически активных веществ.

КЛЮЧЕВЫЕ СЛОВА: сухой экстракт; бархатцев распростертых трава; аминокислоты; высокоэффрективная жидкостная хроматография.

\section{H. R. Kozyr}

I. HORBACHEVSKY TERNOPIL STATE MEDICAL UNIVERSITY

\section{RESEARCH OF AMINO ACID COMPOSITION OF MARIGOLD HERB DRY EXTRACT}

Summary

Introduction. Amino acids of plant origin are easily digestible and are found in biologically available to human body concentrations. Therefore, their research in medicinal plant raw materials and phytopreparations is of great scientific and practical importance.

The aim of the study - to learn the qualitative composition and quantitative content of amino acids in the dry extract of the French marigold herb.

Research Methods. We studied the identification and determination of the quantitative content of free and bound amino acids in the dry extract obtained from the French marigold herb by high-performance liquid chromatography (HPLC).

Results and Discussion. According to the results of the HPLP analysis, 17 amino acids, of which 9 are essential, were identified in the French marigold herb dry extract. It is found that bound amino acids dominated in the composition of an extract. Thus, in percentage equivalent, the content of protein bound amino acids is $97.52 \%$, while the amount of free amino acids is only $2.48 \%$. Among the essential amino acids lysine $(97.76 \mu \mathrm{g} / \mathrm{mg})$, leucine (80.19 $\mu \mathrm{g} / \mathrm{mg})$, phenylalinine $(54.76 \mu \mathrm{g} / \mathrm{mg})$, and isoleucine $(52.40 \mu \mathrm{g} / \mathrm{mg})$ dominated. The lowest content of methionine was in the bound state and its absence - in free. Among the nonessential amino acids, the largest number was of monoamino dicarboxylic acids (glutamine and asparagine) and cystine.

Conclusions. The amino acid composition of the French marigold herb dry extract was studied. Using the HPLC analysis method we investigated the qualitative composition and content of bound protein and free amino acids. The obtained results testify to the promising use of the French marigold herb dry extract as a potential source of biologically active substances.

KEY WORDS: dry extract; French marigold herb; amino acids; high-performance liquid chromatography.

Отримано 02.11.18

Адреса для листування: Г. Р. Козир, Тернопільський державний медичний університет імені І. Я. Горбачевського, майдан Волі, 1, Тернопіль, 46001, Україна, e-mail:kozyr.gr@gmail.com. 